\title{
Twitching motility of Ralstonia solanacearum requires a type IV pilus system
}

\author{
Huanli Liu, ${ }^{1}$ Yaowei Kang, ${ }^{1}$ Stéphane Genin, ${ }^{3}$ Mark A. Schell ${ }^{1,2}$ \\ and Timothy P. Denny ${ }^{1}$
}

Author for correspondence: Timothy P. Denny. Tel: +1 706542 1282. Fax: +1 7065421262.

e-mail:tdenny@arches.uga.edu

1,2 Departments of Plant
Pathology ${ }^{1}$ and
Microbiology ${ }^{2}$, University
of Georgia, Athens,
GA 30602, USA
3 Laboratoire de Biologie
Moléculaire des Relations
Plantes-Micro-
organismes, INRA-CNRS,
Toulouse, France

\section{INTRODUCTION}

Ralstonia solanacearum (previously Pseudomonas solanacearum) is a soil-borne pathogen that causes lethal wilt symptoms in $>200$ plant species around the world, including tomato, potato, peanut and banana (Hayward, 2000). A part-time soil inhabitant, $R$. solanacearum enters plant roots via wounds or where secondary roots emerge, invades xylem vessels, and rapidly spreads throughout the vascular system. Wilting is due

Abbreviations: EPS, extracellular polysaccharide; HR, hypersensitive reaction; Tfp, type IV pili.

\begin{abstract}
Twitching motility is a form of bacterial translocation over firm surfaces that requires retractile type IV pili. Microscopic colonies of Ralstonia solanacearum strains AW1, K60 and GMI1000 growing on the surface of a rich medium solidified with $1.6 \%$ agar appeared to exhibit twitching motility, because early on they divided into motile 'rafts' of cells and later developed protruding 'spearheads' at their margins. Individual motile bacteria were observed only when they were embedded within masses of other cells. Varying degrees of motility were observed for $\mathbf{3 3}$ of $\mathbf{3 5}$ strains of $\boldsymbol{R}$. solanacearum in a selected, diverse collection. Timing was more important than culture conditions for observing motility, because by the time wild-type colonies were easily visible by eye (about $48 \mathrm{~h}$ ) this activity ceased and the spearheads were obscured by continued bacterial multiplication. In contrast, inactivation of PhcA, a transcriptional regulator that is essential for $R$. solanacearum to cause plant disease, resulted in colonies that continued to expand for at least several additional days. Multiple strains with mutations in regulatory genes important for virulence were tested, but all exhibited wild-type motility. Many of the genes required for production of functional type IV pili, and hence for twitching motility, are conserved among unrelated bacteria, and pilD, pilQ and pilT orthologues were identified in $R$. solanacearum. Colonies of $R$. solanacearum pilQ and pilT mutants did not develop spearheads or rafts, confirming that the movement of cells that had been observed was due to twitching motility. Compared to the wild-type parents, both pilQ and pilT mutants caused slower and less severe wilting on susceptible tomato plants. This is the first report of twitching motility by a phytopathogenic bacterium, and the first example where type IV pili appear to contribute significantly to plant pathogenesis.
\end{abstract}

Keywords: pili, fimbriae, bacterial wilt, bacterial cell movement to vascular dysfunction caused by high bacterial cell densities $\left(>10^{9}\right.$ c.f.u. perg fresh weight) and the attendant production of plant-cell-wall-degrading enzymes and copious amounts of a high-molecular-mass extracellular polysaccharide (EPS1) (McGarvey et al., 1999; Schell, 2000).

Efficient colonization of a host plant requires both EPS1 and multiple extracellular proteins (Araud-Razou et al., 1998; Kang et al., 1994; Saile et al., 1997; Schell, 2000). Some extracellular proteins made by $R$. solanacearum are delivered to host cells via a type III secretion system encoded by a cluster of $>20$ hrp genes (Cornelis \& van Gijsegem, 2000; van Gijsegem et al., 1995). These 
'effector' proteins promote bacterial multiplication in hosts and trigger defence responses in nonhosts. Other extracellular proteins, like the plant-cell-wall-degrading enzymes, transit the general secretory pathway (type II secretion) (Hueck, 1998; Pugsley, 1993). Individual enzymes enhance virulence of $R$. solanacearum (e.g. the rate and severity of wilting) (Denny et al., 1990; Huang \& Allen, 1997; Tans-Kersten et al., 1998), but together they may be essential for disease (Kang et al., 1994). Expression of virulence factors, plus other genes not obviously required for virulence, is controlled by a complex, environmentally responsive regulatory network (Schell, 2000). Central to this network is the Phc confinement-sensing system, which employs the PhcA global transcriptional regulator to control multiple genes directly and indirectly. Some PhcA-regulated genes, like the egl endoglucanase and the eps gene cluster, are expressed strongly only at high cell density, whereas others, such as the pglA endo-polygalacturonase, are more highly expressed at low cell density.

To understand better the process of systemic colonization by $R$. solanacearum, we are investigating what role the cell surface components of the pathogen may play during interactions with plant tissues. We are particularly interested in surface molecules that would be exposed when EPS1 is not produced, a condition that occurs when cells are at low density (e.g. early in colonization) (Kang et al., 1999). The obvious candidates are the lipopolysaccharide and pili (fimbriae). However, biosynthesis of lipopolysaccharides is complex, requiring multiple enzymic steps, and the $R$. solanacearum LPS-deficient mutants described to date also have defects in EPS1 synthesis or membrane function (Cook \& Sequeira, 1991; Titarenko et al., 1997). In contrast, pili consist primarily of a single structural protein (pilin), so they are more amenable to reverse genetics to evaluate their role during pathogenesis.

Numerous Gram-negative bacteria, including some animal and plant pathogens, produce type IV pili (Tfp) (Ojanen-Reuhs et al., 1997; Roine et al., 1998; Strom \& Lory, 1993; Su et al., 1999; van Doorn et al., 1994; Wall \& Kaiser, 1999). Depending on the organism, Tfp can be important for adhesion, aggregation, biofilm formation, horizontal gene transfer, multicellular development, pathogenesis and twitching motility (Fussenegger et al., 1997; Merz et al., 2000; Strom \& Lory, 1993; Wall \& Kaiser, 1999). Twitching motility, which is a form of flagella-independent translocation of bacteria over solid surfaces, now appears to be somewhat misnamed, because cell movements can be intermittent and jerky or smooth and prolonged (Henrichsen, 1983; Semmler et al., 1999; Wall \& Kaiser, 1999). The amount of movement necessary to qualify as twitching also varies from almost nonobservable to quite large (e.g. $\geqslant 0.6 \mathrm{~mm} \mathrm{~h}^{-1}$ for Pseudomonas aeruginosa) (Alm \& Mattick, 1997; Henrichsen, 1972, 1983; Semmler et al., 1999; Strom \& Lory, 1993). Retraction of Tfp, probably by filament disassembly, has long been considered the likely mechanism for twitching motility (Bradley,
1980; Wall \& Kaiser, 1999; Wolfgang et al., 2000). Very recently, sophisticated microscopic techniques have provided direct evidence that Tfp are the actuators of cell movement in P. aeruginosa and Myxococcus xanthus (Skerker \& Berg, 2001; Sun et al., 2000) and shown that Neisseria gonorrhoeae Tfp exert sufficient retractile force to move bacterial cells (Merz et al., 2000). Tfp and twitching motility have been studied most in P. aeruginosa, where at least 35 genes are required for synthesis, display and function of polar, retractable Tfp (Alm \& Mattick, 1997; Wall \& Kaiser, 1999). Many genes for production of $\mathrm{Tfp}$, including that for the pilin subunit protein, are well conserved in a variety of bacteria.

We became suspicious that $R$. solanacearum exhibits twitching motility when we noted that young, microscopic colonies growing on the surface of agar media had margins that were serrated and layered in appearance, resembling colonies of twitching $P$. aeruginos pictured in the literature (Bradley, 1980; Darzins, 1993; O’Toole \& Kolter, 1998; Semmler et al., 1999). Our suspicion was reinforced when a subsequent search of the preliminary genomic DNA sequence of $R$. solanacearum strain GMI1000 revealed ORFs that were predicted to encode proteins very similar to many of those that are essential for biosynthesis of Tfp, and hence twitching, in $P$. aeruginosa and other bacteria. In this paper we present strong evidence that $R$. solanacearum exhibits twitching motility using a Tfp system, and that Tfp contribute to pathogenesis on tomato plants.

\section{METHODS}

Strains and culture conditions. The bacterial strains and plasmids used in this study are listed in Tables 1 and 2 . $R$. solanacearum AW1-gfp38, which expresses a modified green fluorescent protein (GFP-mut2) from a constitutive pathogen promoter, was created by randomly mutagenizing AW1 using pUTmini-Tn5gfp as described by Matthysse et al. (1996). The selected strain was chosen based on its bright fluorescence, wild-type multiplication and colony morphology in culture, and wild-type virulence on tomato plants. Escherichia coli strain DH5 $\alpha$ (Gibco-BRL) was used as the host for maintenance of plasmids. $R$. solanacearum strains were cultured routinely at $30{ }^{\circ} \mathrm{C}$ in $\mathrm{BG}$ broth $(1 \%$ Bacto peptone, $0 \cdot 1 \%$ Casamino acids, $0 \cdot 1 \%$ yeast extract, $0.5 \%$ glucose) or BG agar (BG broth $+1.6 \%$ agar). Other media used were EG broth (Brumbley \& Denny, 1990) and a liquid minimal medium (MM) (Clough et al., 1994) that was solidified with $1.6 \%$ agar when desired. When they were to be used for observing twitching motility, freshly poured plates were dried by temporarily removing their lids and placing them either inverted in a $37^{\circ} \mathrm{C}$ incubator for $10 \mathrm{~min}$ or upright at room temperature in a laminar-flow hood for $15 \mathrm{~min}$. After inoculation, plates were incubated in a gravity convection incubator (i.e. without a fan). E. coli and P. aeruginosa strains were cultured routinely at $37^{\circ} \mathrm{C}$ in Luria-Bertani (LB) broth or LB agar (Miller, 1972). Antibiotics used were ampicillin (Ap, $\left.100 \mu \mathrm{g} \mathrm{ml}^{-1}\right)$, gentamicin $\left(\mathrm{Gm}, 5-10 \mu \mathrm{g} \mathrm{ml}^{-1}\right)$, kanamycin $(\mathrm{Km}$, $\left.50 \mu \mathrm{g} \mathrm{m}^{-1}\right)$, nalidixic acid $\left(\mathrm{Nx}, 20 \mu \mathrm{g} \mathrm{ml}^{-1}\right)$, spectinomycin $\left(\mathrm{Sp}, 50 \mu \mathrm{g} \mathrm{ml}^{-1}\right)$ and tetracycline $\left(\mathrm{Tc}, 15 \mu \mathrm{g} \mathrm{ml}^{-1}\right)$.

Assay methods. To quantify EPS1, endoglucanase activity or endo-polygalacturonase activity, $R$. solanacearum was cul- 
Table 1. Strains and plasmids used in this study

\begin{tabular}{|c|c|c|}
\hline Strain or plasmid & Relevant genotype or characteristics" & Reference or source \\
\hline \multicolumn{3}{|l|}{ Strains } \\
\hline \multicolumn{3}{|l|}{ R. solanacearum } \\
\hline AW1 & $\mathrm{Nx}^{\mathrm{r}}$ derivative of wild-type $\mathrm{AW}, \mathrm{Tfp}^{+} \mathrm{Twt}^{+} \mathrm{HR}^{+}$ & Denny et al. (1988) \\
\hline AW1-Q & pilQ::nptI, $\mathrm{Twt}^{-} \mathrm{Nx}^{\mathrm{r}} \mathrm{Km}^{\mathrm{r}}$ & This work \\
\hline AW1-T & pilT: :nptI, $\mathrm{Twt}^{-} \mathrm{Nx}^{\mathrm{r}} \mathrm{Km}^{\mathrm{r}}$ & This work \\
\hline K60 & Wild-type, $\mathrm{Tfp}^{+} \mathrm{Twt}^{+}$ & J.S. Huang \\
\hline K60-Q & pilQ::nptI, Twt ${ }^{-} \mathrm{Km}^{\mathrm{r}}$ & This work \\
\hline K60-T & pilT::nptI, Twt $\mathrm{Km}^{\mathrm{r}}$ & This work \\
\hline GMI1000 & Wild-type $\mathrm{Tfp}^{+} \mathrm{Twt}^{+} \mathrm{HR}^{+}$ & van Gijsegem et al. (2000) \\
\hline \multicolumn{3}{|l|}{ P. aeruginosa } \\
\hline PAK & Wild-type, Tfp $^{+}$Twt $^{+}$ & S. Lory \\
\hline $\mathrm{PAK}-\mathrm{D} \Omega$ & $p i l D:: \Omega, \mathrm{Tfp}^{-} \mathrm{Twt}^{-} \mathrm{Sp}^{\mathrm{r}}$ & S. Lory \\
\hline \multicolumn{3}{|l|}{ Plasmids } \\
\hline pGEM-T easy & Cloning vector, $\mathrm{LacZ}^{+} \mathrm{Ap}^{\mathrm{r}}$ & Promega \\
\hline $\mathrm{pKS}-\mathrm{Gm}$ & pBluescript KS II + with aacC1 replacing the SspI fragment, $\mathrm{Ap}^{\mathrm{r}} \mathrm{Gm}^{\mathrm{r}}$ & This work \\
\hline pKSL & pKS-Gm $\Delta$ SmaI-HincII, Ap $^{r}$ Gm $^{r}$ & This work \\
\hline pTOK2 & Integration vector, ColE1 $\mathrm{Tc}^{\mathrm{r}}$ & Kitten \& Willis (1996) \\
\hline pRK415 & Broad-host-range vector, $\mathrm{Tc}^{\mathrm{r}}$ & Keen et al. (1988) \\
\hline pLAFR3 & Broad-host-range vector, $\mathrm{Tc}^{\mathrm{r}}$ & Staskawicz et al. (1987) \\
\hline pPILQ1 & $1 \cdot 3 \mathrm{~kb}$ PCR fragment internal to pilQ in pGEM-T easy, Ap ${ }^{\mathrm{r}}$ & This work \\
\hline pPILQ2 & $2 \cdot 2 \mathrm{~kb}$ PCR fragment with pilQ in pGEM-T easy, $\mathrm{Ap}^{\mathrm{r}}$ & This work \\
\hline pKSLQ1 & $1.3 \mathrm{~kb} X b a \mathrm{I}$ fragment with pilQ segment from pPILQ1 in pKSL, $\mathrm{Ap}^{\mathrm{r}} \mathrm{Gm}^{\mathrm{r}}$ & This work \\
\hline pKSLQ1::npt1 & pKSQL1 with $n p t I$ replacing the $96 \mathrm{bp}$ PstI fragment of pilQ, $\mathrm{Ap}^{\mathrm{r}} \mathrm{Gm}^{\mathrm{r}} \mathrm{Km}^{\mathrm{r}}$ & This work \\
\hline pTOQ1::npt1 & NotI fragment with pilQ::nptI from pSLQ1::npt1 in pTOK2, Tc ${ }^{\mathrm{r}} \mathrm{Km}^{\mathrm{r}}$ & This work \\
\hline $\mathrm{pRQ} 2+, \mathrm{pRQ} 2-$ & $\begin{array}{l}2 \cdot 2 \mathrm{~kb} \mathrm{XbaI} \text { fragment with pilQ from pPILQ2 in pRK415 }(+, \text { aligned with lac } \\
\text { promoter; -, opposite to lac promoter), } \mathrm{Tc}^{\mathrm{r}}\end{array}$ & This work \\
\hline pPILT & $1 \cdot 2 \mathrm{~kb}$ PCR fragment with pilT in pGEM-T easy, $\mathrm{Ap}^{\mathrm{r}}$ & This work \\
\hline pKSLT & $1 \cdot 2 \mathrm{~kb} \mathrm{XbaI}$ fragment with pilT from pPILT in pKSL, $\mathrm{Ap}^{\mathrm{r}} \mathrm{Gm}^{\mathrm{r}}$ & This work \\
\hline pKSLT: : npt1 & pKSLT with $n p t I$ in the unique EcoRI site of $p i l T, \mathrm{Ap}^{\mathrm{r}} \mathrm{Gm}^{\mathrm{r}} \mathrm{Km}^{\mathrm{r}}$ & This work \\
\hline pTOT::npt1 & XbaI fragment with pilT::nptI from pKSLT : :nptI in pTOK2 $\mathrm{Tc}^{\mathrm{r}} \mathrm{Km}^{\mathrm{r}}$ & This work \\
\hline $\mathrm{pRT}+, \mathrm{pRT}-$ & $\begin{array}{l}1.2 \mathrm{~kb} X b a \mathrm{I} \text { fragment with pilT from pPILT in pRK415 }(+, \text { aligned with lac } \\
\text { promoter; }- \text {, opposite to } l a c \text { promoter }), \mathrm{Tc}^{\mathrm{r}}\end{array}$ & This work \\
\hline pLAD1, pLAD2 & AW1 genomic library clones in pLAFR3, restore twitching to PAK-D $\Omega \mathrm{Tc}^{\mathrm{r}}$ & This work \\
\hline
\end{tabular}

*Twt, twitching motility; Tfp, type IV pili; HR, hypersensitive response on tobacco. Ap ${ }^{\mathrm{r}}, \mathrm{Gm}^{\mathrm{r}}, \mathrm{Km}^{\mathrm{r}}, \mathrm{Nx}^{\mathrm{r}}, \mathrm{Tc}^{\mathrm{r}}, \mathrm{Sp}^{\mathrm{r}}, \mathrm{resistant}$ to ampicillin, gentamicin, kanamycin, nalidixic acid, tetracycline and spectinomycin, respectively.

tured in EG broth, and culture supernatants assayed as described previously (Brumbley \& Denny, 1990; Clough et al., 1994). The method used to monitor $P$. aeruginosa extracellular lipase activity on agar plates was similar to that described previously (Kagami et al., 1998; Roine et al., 1998) except that we used MM agar modified by omitting citric acid and adding olive oil $(0 \cdot 5 \%, \mathrm{v} / \mathrm{v})$ and bromothymol blue $\left(40 \mu \mathrm{g} \mathrm{ml}^{-1}\right)$. This medium selects for cells that produce lipase, because they can grow on the fatty acids released from the olive oil as their sole carbon source; the resulting colonies are surrounded by a yellow halo due to acidification of the medium.

To test the virulence of $R$. solanacearum on tomato plants, seeds (Lycopersicon esculentum Mill., cultivar Marion) were germinated in vermiculite and 2-week old seedlings were transplanted into 4 inch $(10 \mathrm{~cm})$ plastic pots containing a mixture of composted pine bark and vermiculite $(3: 1)$ amended with lime and fertilizer. Plants were incubated in a growth chamber (constant $30^{\circ} \mathrm{C}, 13 \mathrm{~h}$ photoperiod) for $4-5$ weeks before inoculation. Unwounded roots were inoculated by drenching the soil with $40 \mathrm{ml}$ of a bacterial suspension in water, containing $\leqslant 2 \times 10^{8}$ c.f.u. $\mathrm{ml}^{-1}$, prepared as described by Saile et al. (1997). Leaf petioles were inoculated by excising the first leaves above the cotyledon 0.5 to $1 \mathrm{~cm}$ from their base, and immediately applying to the cut surfaces a $2 \mu \mathrm{l}$ droplet of a water suspension containing $8 \times 10^{4}$ c.f.u. of $R$. solanacearum cells taken from a 2-d-old BG agar plate. To test for elicitation of the defensive hypersensitive reaction (HR), water suspensions with $1 \times 10^{7}$ c.f.u. $\mathrm{ml}^{-1}$ of $R$. solanacearum taken from BG agar plates were infiltrated into leaves of tobacco (a nonhost plant) by making a hole in the leaf with a 25 -gauge hypodermic needle, pressing the blunt end of a filled tuberculin syringe against the leaf surface while supporting the other side of the leaf with a finger, and gently injecting a small volume of inoculum (Carney \& Denny, 1990).

Microscopy. Colonies were examined for twitching motility by placing a Petri dish without its lid on the stage of an upright light microscope (Nikon Labophot) equipped with $4 \times$ and $10 \times$ objectives. Digital images were acquired using a colour 
CoolSnap CCD camera (Roper Scientific) and saved as uncompressed TIFF files. Image processing, which was limited to cropping, conversion to greyscale, and adjustment of brightness and/or contrast, was done with CoolSnap or Photoshop (Adobe) software.

Isolation of an $\boldsymbol{R}$. solanacearum cosmid clone with PilD-like activity. A pre-existing, en masse cosmid library of total DNA from strain AW1 (Carney \& Denny, 1990) was introduced into $P$. aeruginosa strain PAK-D $\Omega(p i l D:: \Omega)$ by triparental mating, and Sp- and Tc-resistant transconjugants were selected on lipase activity agar plates. Colonies that acidified the surrounding medium were identified and restreaked on the same medium to confirm restoration of lipase activity and to check for twitching motility.

Plasmid construction. To create pKS-Gm, the $0.85 \mathrm{~kb}$ aacC1 gentamicin-resistance gene cartridge was released from pUCGM (Schweizer, 1993) by digestion with SmaI and was cloned into pBluescript KS II + (Stratagene) that had been digested with $S$ spI (which releases a 131 bp fragment outside of the multiple cloning site). pKSL was created by deleting the SmaI-HincII fragment from within the multiple cloning site of pKS-Gm.

Cloning of $\boldsymbol{R}$. solanacearum pil genes and creation of pil mutants. $R$. solanacearum genes involved in Tfp production were assigned names based on homology and the naming scheme used for $P$. aeruginosa (Alm \& Mattick, 1997). The putative pilQ and pilT genes in $R$. solanacearum were identified in the genome sequence of strain GMI1000 using tBLASTn (Altschul et al., 1997) with the P. aeruginosa PilQ and PilT protein sequences as probes. PCR primers were designed to amplify the complete pilQ gene ( $2178 \mathrm{bp}$ fragment: forward 5'-TACCTCTAGAGACCCTGAAAGTTCAGGAGGGCGG-3', reverse 5'-TACCTCTAGACTTCAGCGACAGCTGGTCGGACAG-3'), an internal portion of pilQ (1336 bp fragment: forward 5'-TACCTCTAGAGCACCCGCGTCGTGCTGGATCTGG, reverse 5'-TACCTCTAGATCGGTACCCTGCTCGATCAGCGCC-3') and the complete pilT gene (1190 bp fragment: forward 5'-GGTACCTCTAGA CATCGTGGCACTCCGGAGC-3', reverse 5'-GGTACCTCTAGACAAGTCCGAGCCACGGCTG-3'). Each primer had an $X b a$ I site incorporated into it (nucleotides underlined above) for use in subsequent cloning steps. PCR was performed using standard conditions $\left(94^{\circ} \mathrm{C}\right.$ for $4 \mathrm{~min} ; 30$ cycles of $94^{\circ} \mathrm{C}$ for $1 \mathrm{~min}, 60^{\circ} \mathrm{C}$ for $1.5 \mathrm{~min}, 72^{\circ} \mathrm{C}$ for $2 \mathrm{~min} ; 72^{\circ} \mathrm{C}$ for $10 \mathrm{~min}$ ) with AW1 genomic DNA as the template and the reaction products were resolved by agarose gel electrophoresis. Amplified fragments were purified from the gel using the QIAquick Gel Extraction Kit (Qiagen), cloned onto pGEM-T easy, and sequenced using vector primer sites. The $X b a \mathrm{I}$ fragments with the $1.3 \mathrm{~kb}$ pilQ internal fragment and the pilT gene were subcloned separately onto the $\mathrm{XbaI}$ site in pKSL to create pKSLQ1and pKSLT, respectively. Inactivated alleles of each gene were made by inserting the $0.9 \mathrm{~kb}$ nonpolar $n p t I$ cartridge (encoding $\mathrm{Km}$ resistance) (Galan et al., 1992) to create pKSLQ1::npt1 and pKSLT::npt1. The pilQ::nptI and pilT::nptI constructs were released by digestion with NotI or $X b a \mathrm{I}$, respectively, and cloned into similarly digested pTOK2 to create pTOQ1::npt1 and pTOT::npt1. The inactivated alleles were introduced into AW1 and K60 wild-type strains by electroporation of purified plasmid DNA. pTOK2 cannot replicate in $R$. solanacearum, so selection for Km-resistance followed by screening for Tc-sensitivity returned colonies where the wild-type gene on the chromosome had been sitespecifically replaced with the inactivated allele. Fidelity of replacement was checked by: (1) determining whether genomic DNA from a mutant simultaneously transformed wild-type strains to $\mathrm{Km}$ resistance and the mutant's phenotype; and (2) PCR amplification of the wild-type or inactivated allele using primers flanking the gene and analysis of the fragment sizes by agarose-gel electrophoresis. The complete pilQ and pilT genes also were subcloned in both orientations in pRK415 (Keen et al., 1988) to create plasmids pRQ2+, pRQ2 -, pRT + and pRT -, respectively.

Recombinant DNA techniques and DNA sequence analysis. Standard protocols were used for cloning, conjugation, electroporation, preparation of competent cells and Southern blotting (Ausubel et al., 1989; Carney \& Denny, 1990). Hybridization to Southern blots used the DIG High Prime labelling and detection kit (Roche Molecular Biochemicals) and followed the manufacturer's protocols. Plasmid DNA was isolated using a Qiagen mini kit, and genomic DNA by the method of Chen \& Kuo (1993). Natural transformation of $R$. solanacearum with genomic DNA was similar to that described by Bertolla et al. (1997), except that BG agar plates were used and the mixture of bacteria and DNA was incubated directly on the agar plate for 18-24 h. Restriction enzymes were purchased from New England Biolabs and the MasterAmp $T f l$ DNA polymerase PCR kit was from Epicentre Technologies. DNA primer synthesis and DNA sequencing were performed at the University of Georgia Molecular Genetics Instrumentation Facility.

\section{RESULTS}

\section{R. solanacearum exhibits twitching motility in culture}

Light microscopy revealed that young colonies (about $20 \mathrm{~h}$ old) of the wild-type strains AW1, K60 and GMI1000 growing on the surface of BG agar plates had various micromorphologies, which included separate irregular rafts or tendrils (Fig. 1a), a diffuse growth over much of a circular area (Fig. 1b), and a ring with mostly empty centres (Fig. 1c). Colonies that were $24 \mathrm{~h}$ old sometimes had a reticulate appearance (Fig. 1d) or were confluent, with ragged edges (Fig. 1e). By the time colonies were $30 \mathrm{~h}$ old they typically had thin or layered edges with multiple irregular projections ('spearheads') (Fig. 1f, g). Colonies of an EPS1 ${ }^{-}$mutant were indistinguishable from those of the wild-type throughout these early stages of development. By the time the $R$. solanacearum colonies became visible by eye (about $42 \mathrm{~h}$ ), the spearheads were becoming obscured by overgrowth of cells from the centre of the colony and also by EPS1 production in the wild-type (Fig. 1h). By $50 \mathrm{~h}$, the spearheads were almost or completely obscured (Fig. 1i). Colony margins of twitching-positive P. aeruginosa strains PAO1 and PAK growing on the surface of BG plates had very irregularly shaped spearheads, and often there were rafts of bacteria separated from the colony (results not shown). Unlike wild-type $R$. solanacearum, isolated $P$. aeruginosa colonies continued to expand for $>3 \mathrm{~d}$, and spearheads at the margins did not become obscured by overgrowths of cells from the centre of the colonies.

To prove that the remarkable $R$. solanacearum colony micromorphology is the result of cells migrating over the agar surface rather than being due to multiplication 

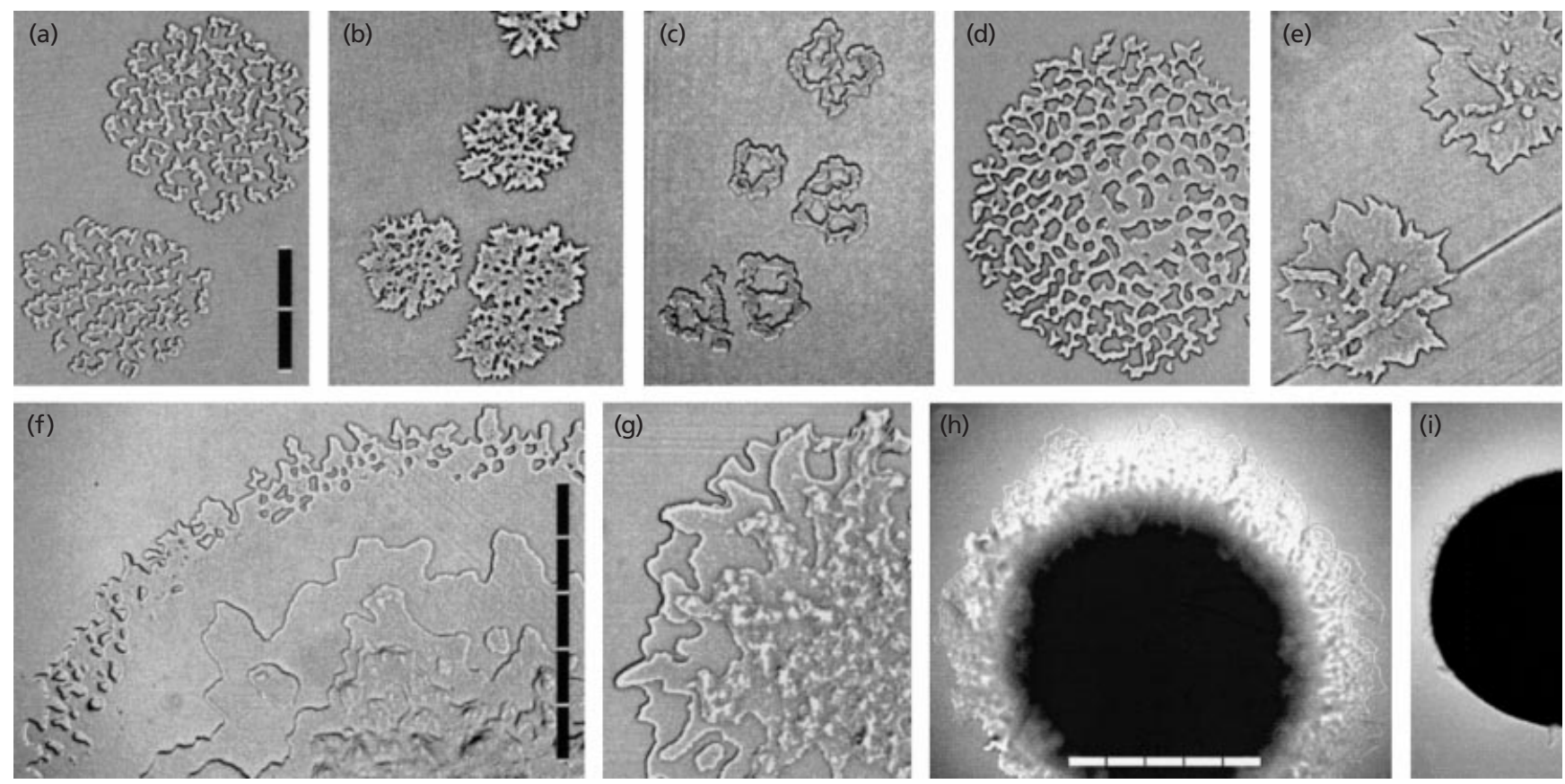

Fig. 1. Typical micromorphology of $R$. solanacearum colonies. Strains were cultured using standard procedures (see Methods) on BG agar plates. Strain AW1 is shown 20, 24, 30, 42 and $50 \mathrm{~h}$ after streaking (a, d, f, h and i, respectively). Strain $\mathrm{K} 60$ is shown after $20 \mathrm{~h}(\mathrm{~b}$ and $\mathrm{c}), 24 \mathrm{~h}(\mathrm{e})$ and $30 \mathrm{~h}(\mathrm{~g})$. Different colonies are shown in each panel. Bars, $0.2 \mathrm{~mm}$ (a-e); $0.5 \mathrm{~mm}$ ( $f$ and $\mathrm{g}$ ); $1.0 \mathrm{~mm}$ ( $\mathrm{h}$ and i).
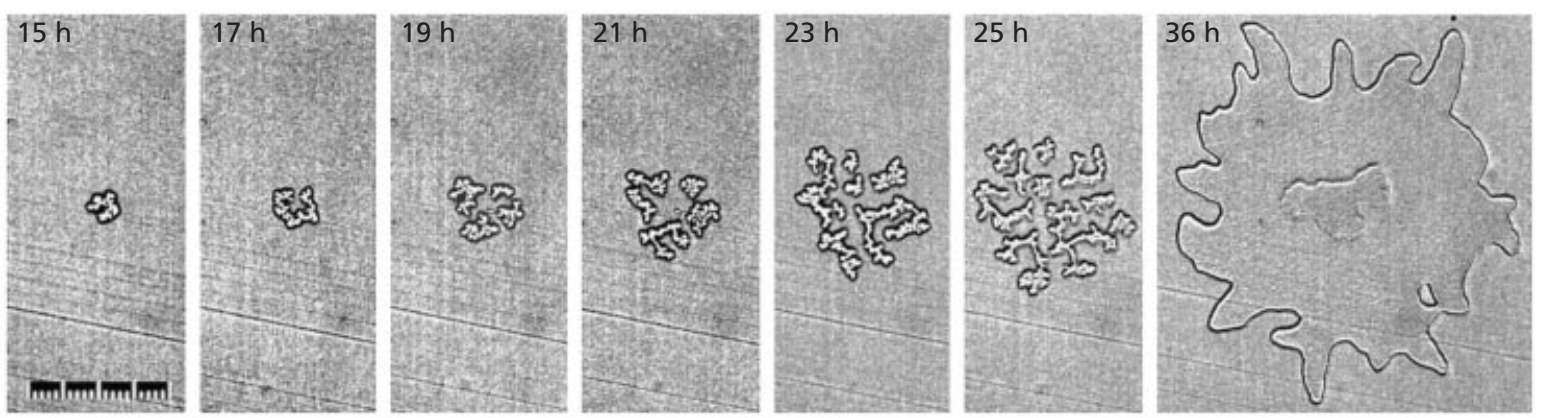

Fig. 2. Time course of $R$. solanacearum micro-colony development. A single colony of K60 growing on BG agar was imaged at hourly intervals from 12 to $25 \mathrm{~h}$ after streaking, and then again at $36 \mathrm{~h}$; selected images are shown. Standard incubation conditions and observation methods were used. Repeated observation retarded colony development relative to that shown in Fig. 1. Bar, $0 \cdot 2 \mathrm{~mm}$ (with $10 \mathrm{~nm}$ subdivisions).

oriented away from the centre of the colony, we looked for individual cells or rafts of cells leaving an area that they had previously occupied. Migration was documented for K60 during development of a single colony by taking images at hourly intervals starting $12 \mathrm{~h}$ after a BG plate was streaked (Fig. 2). When first observed, the colony consisted of a small irregular cluster of cells, but by $19 \mathrm{~h}$ the colony had split into three irregular rafts of cells, leaving what had been the middle of the colony empty. By $25 \mathrm{~h}$ the colony had further expanded and divided into $\geqslant 10$ rafts, leaving much of the space within the roughly circular zone of the colony unoccupied. Colonies at a similar developmental stage were observed routinely for K60 and other R. solanacearum strains in many additional experiments. We did not observe migration of single bacteria away from a raft or spearhead. By $36 \mathrm{~h}$ the rafts had merged, probably by a combination of movement and multiplication (Semmler et al., 1999), to give a thin colony with multiple spearheads at its margin. 

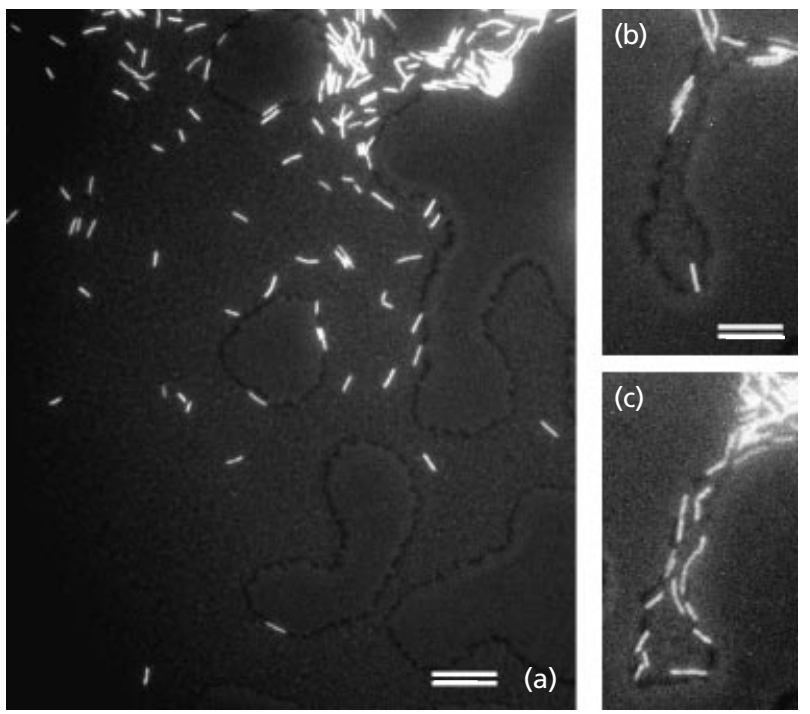

Fig. 3. Movement of single $R$. solanacearum cells. A 10:1 mixture of AW1 (nonfluorescent) and AW1-gfp38 (fluorescent) cells was spread on a BG agar plate, which was subsequently incubated for $24 \mathrm{~h}$. (a) A tendril of an AW1-gpf38 colony at the upper right had fused with the advancing edge of an AW1 colony. Single fluorescent cells were observed deep within the bulk of the nonfluorescent cells. (b, c) The same tendril of a colony containing both types of cells imaged 90 min (about one generation) apart. Numerous fluorescent cells moved into the tendril during this interval. Images were made using combined epifluorescent and low-level transmitted light. Bars, $10 \mathrm{~nm}$.

Movement of individual bacteria was observed within spearheads and rafts by culturing a mixture of fluorescent (AW1-gfp38) and nonfluorescent (AW1) wild-type cells together on a BG agar plate. Where spearheads or rafts from the two strains met during colony development, the cells intermixed to varying degrees. It was common to find isolated fluorescent cells within rafts of nonfluorescent cells (results not shown) or deep within a nonfluorescent colony (Fig. 3a), which could only have got there by migration. In addition, serial images revealed the movement of single fluorescent cells within a raft or spearhead of nonfluorescent cells (Fig. $3 \mathrm{~b}, \mathrm{c})$. These observations show clearly that $R$. solanacearum can migrate over an agar surface, and the genetic evidence presented below shows that this due to twitching motility.

\section{Factors that affect expression of twitching motility in culture}

To optimize twitching motility by wild-type $R$. solanacearum in culture, we tested different conditions using AW1, K60 and GMI1000. The degree of twitching was evaluated qualitatively by observing the size and micromorphology of colonies in low-density areas of plates 20-24 h after streaking. As previously reported (Bradley, 1980; Henrichsen, 1975b), correct preparation of the agar plates was important, with freshly poured and briefly dried plates (see Methods) working better than those $\geqslant 1 \mathrm{~d}$ old. However, all three strains exhibited some twitching motility on 1-d-old plates prepared using standard methods. Incubating inoculated plates in a loosely closed plastic bag along with several moist paper towels to ensure high humidity enhanced the degree of twitching motility and increased colony size (compare Figs $4 \mathrm{a}$ and $4 \mathrm{~b}$ ). Twitching was observed on plates solidified with agarose (Genetic Technology Grade; ICN), but colonies consisted mostly of sinuous tendrils with smooth margins (Fig. 4c). Motility was much better on BG agar plates than on MM agar plates (Fig. 4d), but agar from different companies (Difco or Sigma) did not affect twitching. Agar concentrations ranging from 0.8 to $2.0 \%$ were tested, and plates with $1 \cdot 2-1 \cdot 6 \%$ agar were the best for observing twitching. Results were the same whether cells were applied to plates by streaking, spreading or spotting microdroplets. When plates were stab-inoculated with $R$. solanacearum, twitching motility was observed in the interstitial space between the agar and the polystyrene surface of the Petri dish, but in comparison to colonies on the agar surface, the spearheads were less pronounced and movement away from the point of inoculation was slower. Twitching motility by $P$. aeruginosa responded similarly to most conditions tested, but $P$. aeruginosa
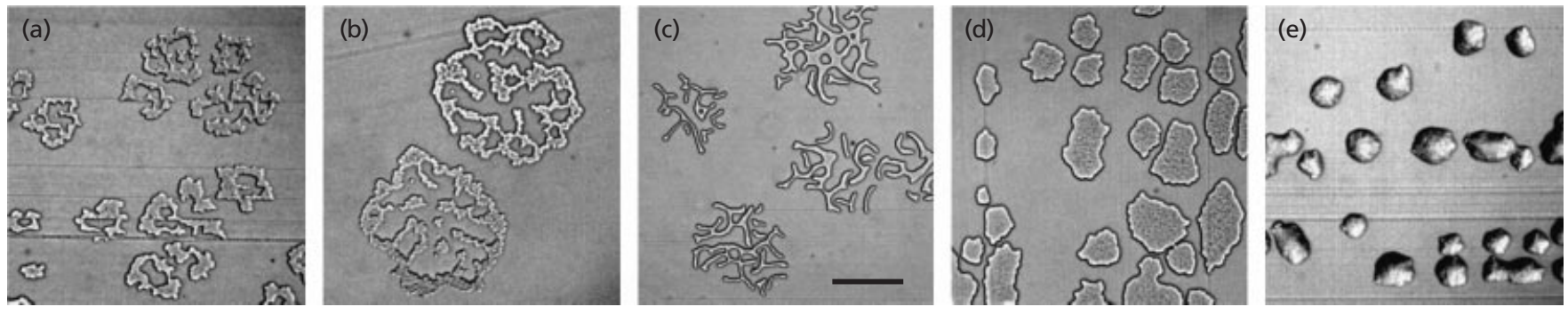

Fig. 4. Micromorphology of $R$. solanacearum wild-type $K 60$ (a-d) and $K 60-Q$ (e) colonies cultured using standard or nonstandard conditions. (a) Standard conditions on BG agar, showing typical morphology. (b) High humidity during incubation on BG agar, showing large colony size. (c) Standard conditions on BG agarose (1.6\%), showing more compact and distinct tendrils. (d) Standard conditions on MM agar, showing reduced twitching activity. (e) Standard conditions on BG agar, showing a pilQ mutant, which does not twitch. Bar, $0.2 \mathrm{~mm}$. 


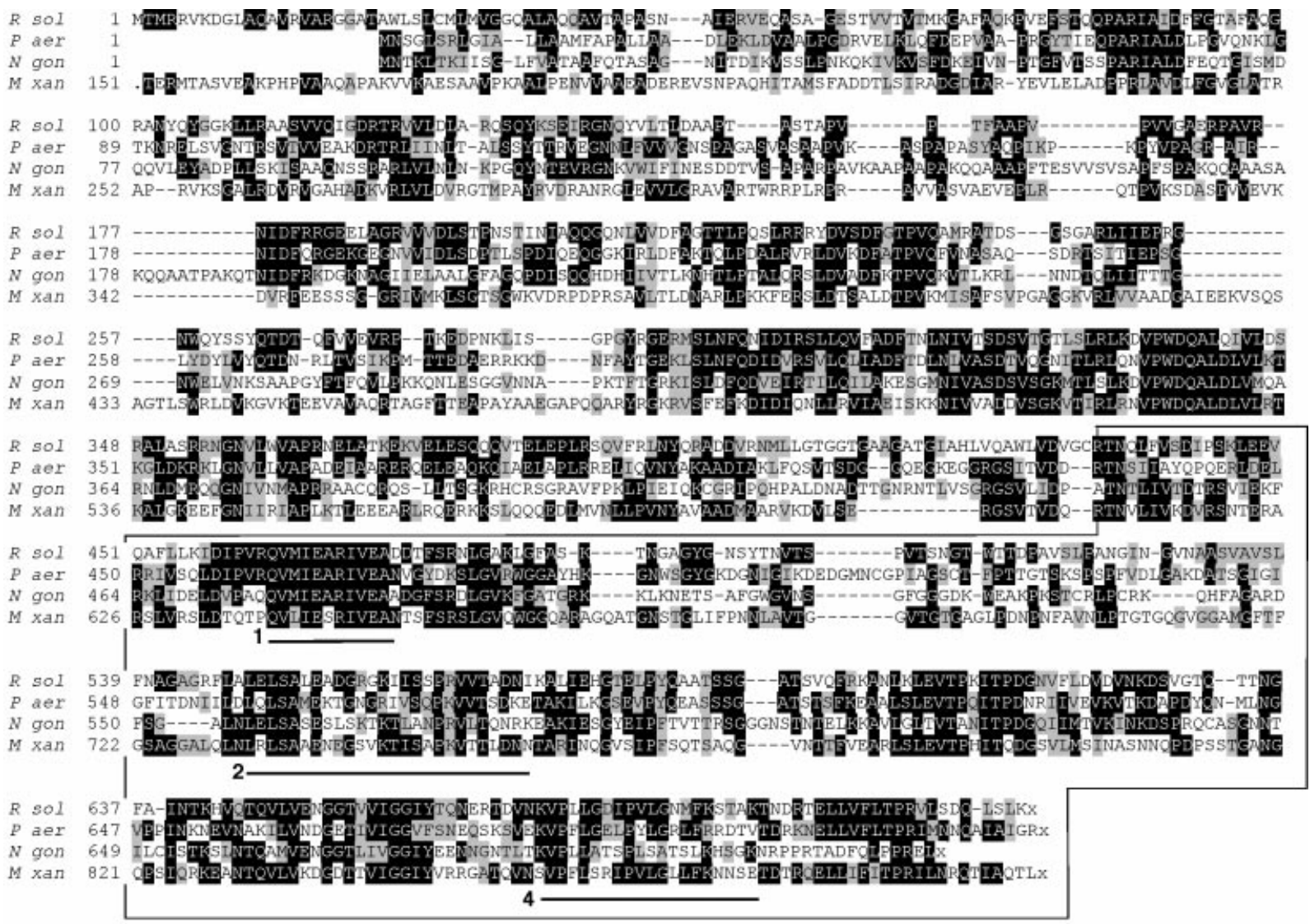

Fig. 5. Predicted amino acid sequence of $R$. solanacearum AW1 PilQ protein and its alignment with selected orthologues. The alignment was generated using CLUSTAL W (http://www.ch.embnet.org) with the default parameters. Amino acids that are identical or similar in $\geqslant 50 \%$ of the sequences are shown in white on black or in black on grey, respectively. An ' $\mathrm{X}$ ' indicates the C-terminus. Homologous PilQ proteins are from $P$. aeruginosa (GenBank accession no. P34750), N. gonorrhoeae (S70838) and M. xanthus (AF100157). The unaligned N-terminal 150 amino acids of M. xanthus PilQ were omitted for simplicity. The C-terminal region (starting with residue 434 of $R$. solanacearum PilQ) that is most conserved among the secretin superfamily is enclosed by a box. The three highly conserved motif sequences are underlined (motifs 1, 2 and 4; see PRINTS accession PR00811).

was much better than $R$. solanacearum in moving between the agar and the Petri dish surface. In summary, only simple procedures and correct timing were necessary to observe twitching motility by $R$. solanacearum.

We investigated the effect that inactivating a variety of regulatory genes had on twitching motility of $R$. solanacearum. Mutants of AW1 that were tested carried single insertions that inactivated either components of the Phc confinement-sensing system ( $p h c A, p h c B$, phcBSR) (Clough et al., 1997b), two two-component systems that regulate EPS production and other virulence factors (vsrAD, vsrBC) (Huang et al., 1995), a unique signal-integrating, trans-acting protein in eps regulation ( $x p s R)$ (Huang et al., 1995), the stationaryphase sigma factor (rpoS) (Flavier et al., 1998), or the acylhomoserine-lactone-responsive quorum-sensing system (solR, solI) (Flavier et al., 1997). Mutants of GMI1000 carried single insertions that inactivated components regulating hrp genes (prhA, prbI, prbJ, hrpG and hrpB) (Brito et al., 1999; Marenda et al.,
1998; Schell, 2000) or $p h c A$. The mutants all exhibited twitching motility that was comparable to that of the parental strains cultured at the same time, except for the phcA mutants, which continued to exhibit twitching motility for days longer than the others. Prolonged motility of bacteria was particularly evident when there were only three or four colonies per plate or if the plate was spot-inoculated at its centre. For example, isolated colonies of the AW1 phcA mutant became about three times the size of EPS1 ${ }^{-}$colonies (e.g. $17 \cdot 2 \mathrm{~mm}$ diameter vs $5.5 \mathrm{~mm}$ after $3 \mathrm{~d}$ incubation). This observation suggests that, like a few other traits, twitching motility is negatively regulated by the increase in PhcA function that occurs when cell density increases (Clough et al., 1997a; Schell, 2000).

Many of the proteins essential for type IV piliation are similar to those required for type II protein secretion across the outer membrane (Nunn, 1999). In P. aeruginosa these similarities are so strong that some proteins in both systems are processed by PilD, a specialized 


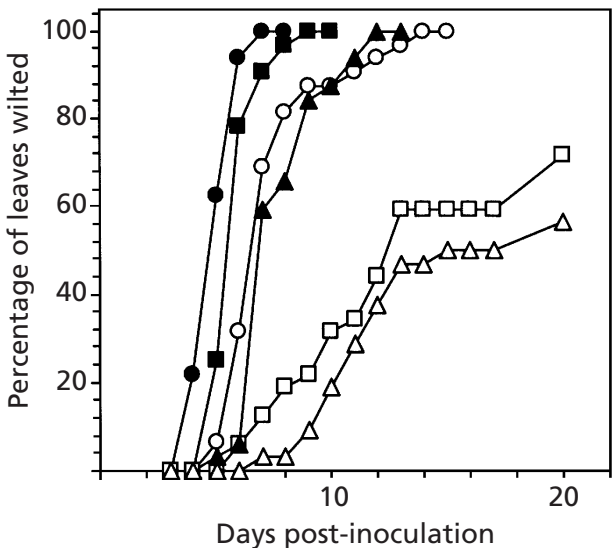

Fig. 6. Virulence of $R$. solanacearum wild-type and a pilQ mutant. Unwounded roots of tomato plants were inoculated by drenching the soil with suspensions of wild-type AW1 (filled symbols) or the pilQ mutant AW1-Q (open symbols) at concentrations of $2 \times 10^{8}$ c.f.u. $\mathrm{ml}^{-1}$ (circles), $2 \times 10^{7}$ c.f.u. $\mathrm{ml}^{-1}$ (squares), or $2 \times 10^{6}$ c.f.u. $\mathrm{ml}^{-1}$ (triangles). Each treatment was applied to eight plants, and the mean percentage of leaves wilted was determined daily. Results are representative of two or more experiments.

leader peptidase (Strom \& Lory, 1993). However, R. solanacearum strain AD4, which has its type II protein secretion system inactivated (Kang et al., 1994), exhibited wild-type twitching activity.

\section{$R$. solanacearum has at least three orthologues of genes essential for production of functional Tfp in $P$. aeruginosa}

Movement of R. solanacearum cells over the surface of agar plates strongly suggests twitching motility, but proof requires documenting that cells become nonmotile when production of functional Tfp is inactivated. Careful examination of the preliminary GMI1000 genomic sequence revealed six ORFs that strongly resemble genes encoding pilin proteins in $P$. aeruginosa and other bacteria, so it will require substantial effort to determine which ORF encodes the pilin protein, as opposed to a pilin-like protein that is involved in biogenesis of Tfp. Therefore, to test more immediately the connection between twitching motility and Tfp, we targeted conserved genes likely to be essential for Tfp production and function.

One of the more conserved R. solanacearum GMI1000 orthologues of interest encodes the putative PilD, which is $41-52 \%$ identical to PilD from $P$. aeruginosa (GenBank accession no. M32066), N. gonorrhoeae (U32588) and M. xanthus (AF003632). In P. aeruginosa, pilD encodes a leader peptidase that processes the $\mathrm{Tfp}$ prepilin protein and $\mathrm{N}$-methylates the pilin $\mathrm{N}$-terminal amino acid (Lory \& Strom, 1997; Strom \& Lory, 1993). PilD peptidase also processes at least six other proteins involved in pilus biogenesis (FimTU, PilE, PilVWX), and five pseudopilins (XcpTUVWX) in the type II secretion system (Alm \& Mattick, 1997; Nunn, 1999). Therefore, $P$. aeruginosa pilD mutants lack twitching motility and do not secrete a lipase and several other extracellular enzymes. We found the $R$. solanacearum pilD orthologue in a cosmid library of AW1 genomic DNA by its ability to restore lipase activity and twitching motility to a $P$. aeruginosa pilD mutant. After an en masse mating, two transconjugant colonies were positive for lipase activity on plates with olive oil as the sole carbon source. Cosmid DNA (pLAD1 and pLAD2) was extracted from each transconjugant, transformed into $E$. coli $\mathrm{DH} 5 \alpha$, and reconjugated into the $P$. aeruginosa pilD mutant. Both cosmids, which contained overlapping regions of the genome, again restored lipase activity and also restored twitching motility, indicating that $R$. solanacearum AW1 has a functional PilD orthologue. Unfortunately, because pilD mutants are pleiotropic, this gene was not a good target to test genetically the connection between Tfp and twitching motility.

A second orthologue of interest was that for pilQ. In $M$. xanthus, N. gonorrhoeae and P. aeruginosa PilQ is a secretin located in the outer membrane, where it is thought to form a gated channel through which the pilin subunits travel (Alm \& Mattick, 1997; Fernandez \& Berenguer, 2000; Wall et al., 1999; Wolfgang et al., 2000). Inactivation of pilQ prevents biogenesis of Tfp, but should have little effect on other secretion systems. In GMI1000, the putative pilQ orthologue is the last gene in what appears to be the pilMNOPQ operon, an organization like that in $P$. aeruginosa and $M$. xanthus (Alm \& Mattick, 1997; Wall \& Kaiser, 1999). We PCRamplified pilQ from the genome of AW1 on a $2.2 \mathrm{~kb}$ fragment, and DNA sequencing showed it to be $89.9 \%$ identical to pilQ in GMI1000. The predicted amino acid sequence of AW1 PilQ has 714 residues and is $91 \%$ identical to the predicted GMI1000 PilQ, and 30-38\% identical to PilQ from M. xanthus, N. gonorrhoeae and $P$. aeruginosa over its entire length (Fig. 5). Like other members of the secretin superfamily (Genin \& Boucher, 1994; Wall et al., 1999), the AW1 PilQ sequence is better conserved in its C-terminal half, with three of the four conserved sequence motifs being present (PRINTS accession PR00811).

The third orthologue we investigated was that for pilT, which encodes one of the most highly conserved proteins required for biogenesis of Tfp in M. xanthus, N. gonorrhoeae and P. aeruginosa (Wall \& Kaiser, 1999). Evidence is building that PilT, which belongs to a family of presumed ATPases, is required for the retraction of Tfp that powers cell movement (Merz et al., 2000; Wall \& Kaiser, 1999; Wolfgang et al., 1998, 2000). Following the same approach as above, we PCR-amplified and cloned the putative pilT from AW1, which DNA sequencing showed to be $96.9 \%$ identical to pilT in GMI1000. The predicted amino acid sequence for AW1 PilT has 347 residues and is $99.7 \%$ identical to the predicted GMI1000 PilT; it is 68 and $71 \%$ identical to PilT from $N$. gonorrboeae and $P$. aeruginosa, respectively. Not surprisingly, AW1 PilT has a conserved Walker box ATP/GTP binding-site [AG]-X ${ }_{4}-\mathrm{G}-\mathrm{K}$-[ST] 
Table 2. Twitching motility and presence of pilQ in a diverse collection of $R$. solanacearum

\begin{tabular}{|c|c|c|c|c|c|c|c|c|}
\hline \multirow[t]{2}{*}{ Strain* } & \multirow[t]{2}{*}{ Twt $†$} & \multirow{2}{*}{ pilQł } & \multirow[t]{2}{*}{ Race } & \multirow[t]{2}{*}{ Biovar } & \multicolumn{2}{|c|}{ RFLP $\mathbb{S}$} & \multirow[t]{2}{*}{ Host } & \multirow[t]{2}{*}{ Origin } \\
\hline & & & & & Division & Group & & \\
\hline AW1 & ++ & + & 1 & 1 & II & ND & Tomato & USA \\
\hline K60 (UW25) & ++ & + & 1 & 1 & II & 1 & Tomato & USA \\
\hline UW26 & ++ & ND & 1 & 1 & II & 2 & Tomato & USA \\
\hline UW30 & ++ & ND & 1 & 1 & II & 1 & Tomato & Trinidad \\
\hline UW134 & ++ & ND & 1 & 1 & II & 1 & Potato & Kenya \\
\hline UW153 & ++ & ND & 1 & 1 & II & 1 & Potato & Australia \\
\hline UW154 & ++ & ND & 1 & 1 & II & 6 & Tobacco & Columbia \\
\hline UW256 & ++ & ND & 1 & 1 & II & 4 & Potato & Costa Rica \\
\hline UW119 & ++ & ND & 1 & 3 & I & 14 & Potato & Costa Rica \\
\hline UW130 & ++ & + & 1 & 3 & I & 9 & Tomato & Peru \\
\hline UW143 & ++ & + & 1 & 3 & I & 10 & Tomato & Australia \\
\hline GMI1000 & ++ & + & 1 & 4 & I & ND & Tomato & French Guyana \\
\hline UW74 & ++ & ND & 1 & 4 & I & 15 & Potato & Sri Lanka \\
\hline UW141 & ++ & ND & 1 & 4 & I & 21 & Ginger & Australia \\
\hline UW151 & ++ & ND & 1 & 4 & I & 22 & Ginger & Australia \\
\hline UW197 & ++ & ND & 1 & 4 & I & 11 & Ginger & The Philippines \\
\hline UW360 & ++ & ND & 1 & 4 & I & 16 & Mulberry & China \\
\hline UW361 & ++ & ND & 1 & 5 & I & 19 & Mulberry & China \\
\hline UW373 & + & ND & 1 & 5 & I & 20 & Mulberry & China \\
\hline UW9 & ++ & ND & 2 & 1 & II & 24 & Heliconia & Costa Rica \\
\hline UW20 & ++ & ND & 2 & 1 & II & 28 & Banana & Venezuela \\
\hline UW28 & - & + & 2 & 1 & II & 24 & Potato & Cyprus \\
\hline UW70 & ++ & + & 2 & 1 & II & 25 & Plantain & Columbia \\
\hline UW127 & ++ & ND & 2 & 1 & II & 25 & Plantain & Peru \\
\hline UW135 & ++ & ND & 2 & 1 & II & 24 & Banana & Honduras \\
\hline UW138 & - & ND & 2 & 1 & II & 25 & Plantain & Costa Rica \\
\hline UW160 & ++ & + & 2 & 1 & II & 25 & Plantain & Peru \\
\hline UW167 & ++ & ND & 2 & 1 & II & 24 & Banana & Costa Rica \\
\hline UW19 & + & + & 3 & 2 & II & 27 & Potato & Columbia \\
\hline UW23 & ++ & + & 3 & 2 & II & 26 & Potato & Israel \\
\hline UW73 & + & ND & 3 & 2 & II & 26 & Potato & Unknown \\
\hline UW80 & + & ND & 3 & 2 & II & 27 & Potato & Columbia \\
\hline UW81 & + \pm & + & 3 & 2 & II & 27 & Potato & Columbia \\
\hline UW145 & + & ND & 3 & 2 & II & 26 & Potato & Australia \\
\hline UW150 & + & ND & 3 & 2 & II & 26 & Potato & Australia \\
\hline
\end{tabular}

*UW strains were from the collection of L. Sequeira (University of Wisconsin). See Cook et al. (1989) for additional information about these strains.

†Degree of twitching motility assessed at $24 \mathrm{~h}$ when cultured using standard conditions on BG agar. ++ , Very active twitching; + \pm , intermediate twitching; +, less active twitching; -, not twitching. See Fig. 7 for examples of the different twitching activities.

$\ddagger$ Southern blots probed with the cloned pilQ. +, Hybridizing band; ND, not done.

\RFLP results are from Cook et al. (1989).

(ProSite PDOC00017) at the expected location (starting with residue 130).

\section{Inactivation of pilQ or pilT eliminates twitching motility and reduces virulence of $R$. solanacearum}

To inactivate pilQ in $R$. solanacearum, we inserted an $n p t I$ ( $\mathrm{Km}$ resistance) cartridge into an internal $1.3 \mathrm{~kb}$ pilQ gene fragment and introduced this into the genome of AW1 and K60 by allelic replacement to create strains
AW1-Q and K60-Q, respectively. As expected, the $R$. solanacearum pilQ mutants did not exhibit twitching motility on BG agar plates, since colonies less than $24 \mathrm{~h}$ old had entire margins, and were smaller and more domed than those of the wild-type parents (Fig. 4e). Nevertheless, 2-d-old colonies of the pilQ mutants on BG agar plates were very similar to those of the wildtypes. Introduction of wild-type pilQ on pRQ2 +, which has the gene on a $2.2 \mathrm{~kb}$ fragment aligned with the vector's lac promoter, into the pilQ mutants restored 
$20 h, 4 \times$

(a)

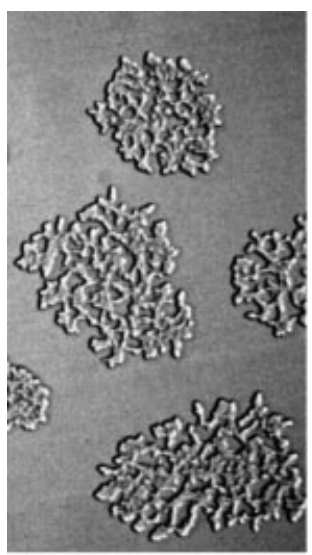

(b)

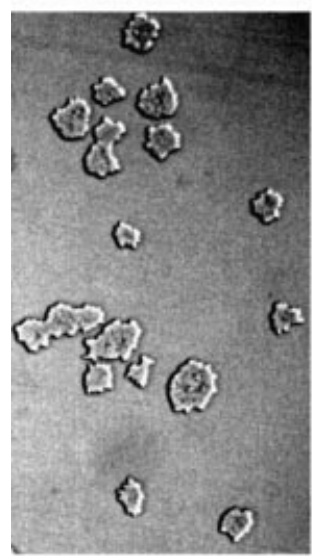

(c)

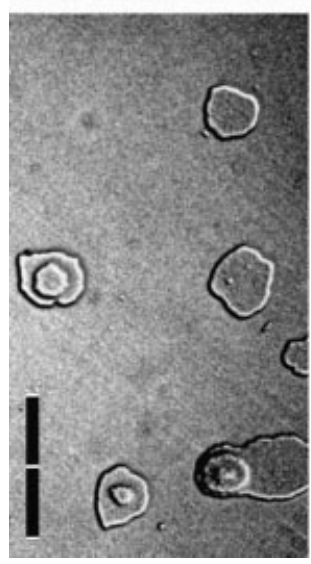

$24 \mathrm{~h}, 10 \times$
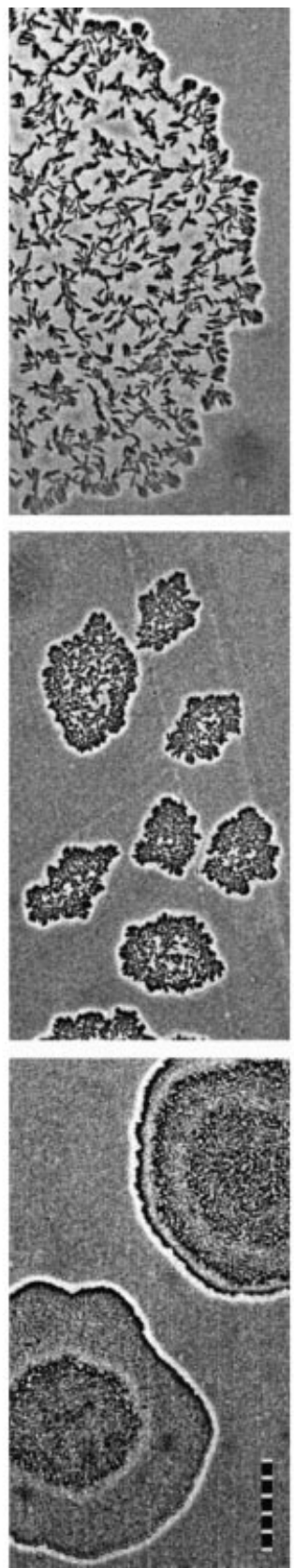

$40 h, 4 \times$
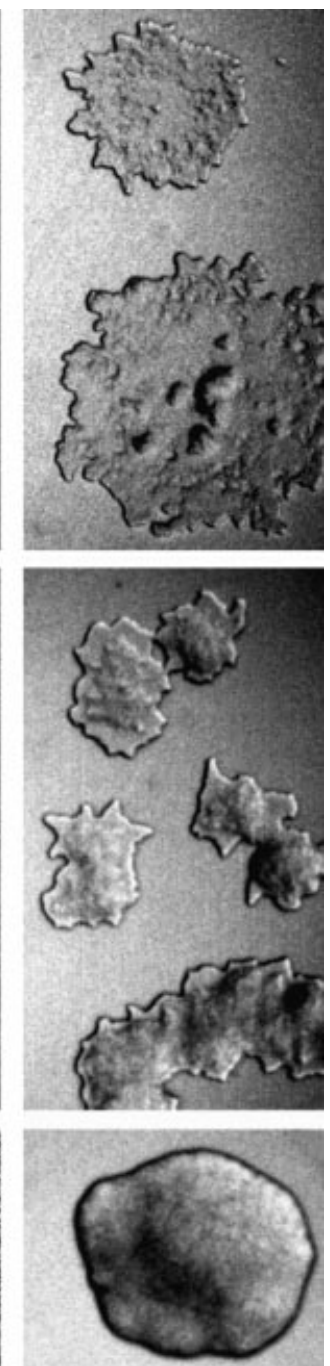

Fig. 7. $R$. solanacearum strains naturally exhibiting different degrees of twitching motility. Each row of images (a-c) illustrates one of the three twitching categories in Table 2. Images in each column were recorded at the indicated time and objective power. (a) Strain UW153 had Twt ++ activity. (B) Strain UW145 had Twt + activity. (C) Strain UW138 had Twt - activity. Bars, $0.2 \mathrm{~mm}$ (first and third columns); $50 \mathrm{~nm}$ (middle column).

twitching motility (not shown), so the $n p t I$ insertion in the genome did not have any obvious effects on downstream genes. pRQ2-, in which pilQ is aligned opposite to the vector's lac promoter, did not restore motility, so the cloned fragment lacks its native promoter as one would expect for a gene located at the end of a large operon.

pilT was inactivated in the genome of AW1 and K60 by allelic replacement, creating strains AW1-T and K60-T. Compared to their wild-type parents, PilT mutants formed a more substantial pellicle at the surface of unshaken cultures or developed as macroscopic clumps of cells that settled to the bottom of the culture tube, suggesting that they are hyperpiliated. Neither AW1-T nor K60-T exhibited twitching motility on BG agar plates, since 24-h-old colonies looked the same as pilQ mutants (not shown). However, 2-d-old cultures of the pilT mutants on BG agar plates had smaller colonies than wild-type, less EPS1 slime, and the slime produced was abnormally transparent due to there being fewer suspended cells.

pilQ and pilT mutants of AW1 and K60 multiplied normally in BG broth cultures, and AW1-Q survived as well as AW1 during the first $7 \mathrm{~d}$ after application to the potting mixture used for growing tomato plants (results not shown). To test whether inactivation of pilQ or pilT 
affected important extracellular products that contribute to virulence of $R$. solanacearum, we quantified EPS1 production, and the activities of two secreted enzymes (endoglucanase and endo-polygalacturonase). The mutants were comparable to the wild-type in all three traits, so the membrane-localized functions for EPS1 biosynthesis and type II secretion were not affected. Like AW1, both AW1-Q and AW1-T elicited a normal HR defence response when infiltrated into nonhost tobacco leaves, so Hrp pili and the rest of the type III protein secretion system also were not affected. However, AW1$\mathrm{Q}$ induced wilt symptoms less quickly than did AW1 when unwounded tomato roots were inoculated by a soil drench (Fig. 6). Although tested less extensively, K60-Q was comparable to AW1-Q in virulence (results not shown). The difference between AW1 and AW1-Q was clearly affected by the inoculum concentration, with higher concentrations of bacteria (e.g. $2 \times 10^{8}$ c.f.u. $\mathrm{ml}^{-1}$ ) markedly reducing the differential between the wild-type and the mutant in some experiments. In three experiments, K60-T wilted plants less quickly than K60 when inoculated via wounded petioles (results not shown). These results suggest that $R$. solanacearum Tfp, or functions that require Tfp, are important during both invasion and colonization of young tomato plants.

\section{Twitching motility is widespread in $R$. solanacearum}

To learn whether twitching motility is a common trait in $R$. solanacearum, we examined the colony micromorphology of a diverse set of 35 strains under standard conditions (Table 2). Thirty-three strains exhibited twitching motility, with the race 1 and 2 strains generally twitching more actively than the race 3 strains. Two strains were nonmotile, because their colonies resembled those of nontwitching $R$. solanacearum pilQ mutants. The differences between the different twitching categories are illustrated in Fig. 7. Except for the less active twitching in most race 3 strains, there was no correlation between the twitching motility and biovar, restriction fragment length polymorphism (RFLP) division, RFLP group, or the host or country from which the strain originated. Southern-blot analysis of $11 R$. solanacearum strains using pPILQ1 as the probe revealed that all of them, including the nonmotile strain UW28, had a single fragment that hybridized (Table 2 and results not shown). The four different bands that hybridized to the pilQ probe ranged in size from 7 to $10 \mathrm{~kb}$, but the RFLP polymorphisms did not correlate with any of the other characteristics listed in Table 2.

\section{DISCUSSION}

Our results revealed that during wild-type colony development $R$. solanacearum has the ability to migrate over an agar surface and that migration of the two strains examined in detail apparently required production of functional Tfp. We referred to this movement as twitching motility, because it closely resembles the Tfp-dependent phenomenon in well-studied strains of P. aeruginosa (Bradley, 1980; Darzins, 1993; Semmler et al., 1999). As previously reported for $P$. aeruginosa (Bradley, 1980; Semmler et al., 1999), we saw smooth movement of $R$. solanacearum in cellular aggregates rather than intermittent and jerky movement of single cells characteristic of the twitching motility reported by Henrichsen (1972). However, the movements Henrichsen used to differentiate twitching and gliding motility (Henrichsen, 1972) seem subtle and subjective, and even he sometimes had trouble making clear distinctions between these motions (Henrichsen, 1975a). We agree with the conclusion of Semmler et al. (1999) that, according to Henrichsen's definitions, because the movement of $P$. aeruginosa and $R$. solanacearum was 'continuous and regularly follows the long axis of the cells which are predominantly aggregated in bundles', it could alternatively be called gliding motility.

We were surprised to find, when researching the older literature on twitching motility, that Henrichsen (1975a, 1983) reported many years ago that five strains of $R$. solanacearum exhibited twitching motility. These results were largely forgotten by the scientific community studying this plant pathogen for several reasons. First, until recently twitching motility was not a commonly studied phenomenon so most plant pathologists were (and are) unfamiliar with it. Second, because Henrichsen surveyed many bacteria in addition to $R$. solanacearum, it was not mentioned by name in the abstract, so only the most thorough or directed literature search would have found these reports.

In our study, motility by $R$. solanacearum clearly was much better on a normal agar surface than in the interstitial space between the agar and the plastic Petri dish, in contrast with $P$. aeruginosa, which migrated quickly in both locations. Unlike Semmler et al. (1999), we observed that $P$. aeruginosa (i) readily developed rafts when growing on the agar-air interface of BG plates and (ii) did not twitch well on the basal agar surface that was exposed by inverting the agar layer. In addition, in contrast to the results of Henrichsen (1975b) with Acinetobacter calcoaceticus, motility of $R$. solanacearum was observed on media solidified with agarose. Therefore, neither BG agarose nor a BG agar surface that solidified while exposed to air was inherently suboptimal for observing twitching motility in vitro. At least for $R$. solanacearum, we found that rather than special conditions being required to observe twitching motility, it is more important that one observe the appropriate strains at the correct time.

Twitching motility has not been reported for other plant-pathogenic bacteria, but several xanthomonads and one pseudomonad make typical Tfp. Pili of Xanthomonas campestris pv. hyacinthi were purified, and the $\mathrm{N}$-terminal amino acid sequence strongly resembled the conserved portion of Tfp (van Doorn et al., 1994). Cells and pili bound to the stomata of hyacinth leaves, but a nonpiliated mutant was not tested so the role of Tfp in pathogenesis on hyacinth remains unclear. For Xanthomonas campestris pv. vesicatoria, the pilin structural gene was found by reverse genetics and 
subsequently inactivated. The nonpiliated mutant retained full virulence on tomato plants when tested under controlled conditions, but because Tfp promoted aggregation on leaf surfaces and increased resistance to killing by UV light the authors speculated that piliation might increase survival on leaf surfaces (Ojanen-Reuhs et al., 1997). Similarly, the Tfp of Xanthomonas campestris pv. citri were reportedly not important for virulence when a nonpiliated mutant was sprayed on citrus leaves in a humid environment (Su et al., 1999). It would have been more interesting and informative if these pathogens had been tested on plants in environmental conditions that resemble natural settings. One example where a mutant strain lacking Tfp was tested in the field was for Pseudomonas syringae pv. tomato (Roine et al., 1998). Even here, however, Tfp did not contribute measurably to virulence, although piliation was again associated with UV tolerance and survival on the leaf surface. Xylella fastidiosa probably makes Tfp, because 26 orthologous genes for pili synthesis and function were found in its genomic sequence (Simpson et al., 2000), but this remains to be proven.

We did not demonstrate the physical presence of Tfp on $R$. solanacearum, but the literature suggests that this organism can make two or more types of pili. In the only contemporary research, van Gijsegem et al. (2000) observed two types of polar pili on GMI1000 during electron microscopy of negatively stained cells. One type of pilus was $3-5 \mathrm{~nm}$ wide and was produced preferentially when cells were cultured on rich medium, but was not further characterized. The second type of pilus had a constant diameter of $6 \cdot 6 \pm 1 \mathrm{~nm}$ and it is composed of $7 \mathrm{kDa}$ pilin monomers encoded by hrpY. The HrpY pilin has a much lower molecular mass than a typical type IV pilin $(16-17 \mathrm{kDa})$, and its amino acid sequence is completely unrelated. It was clear from our results that neither Hrp pili nor any of the Hrp regulatory system tested were necessary for twitching motility.

In the older literature on R. solanacearum, it is not clear what type of pili were detected. The first report was by Fuerst \& Hayward (1969), who observed sparse, polar pili on wild-type biovar 2, 3 and 4 strains. Interestingly, the biovar 4 strain $003 \mathrm{~A}$ they reported using is probably similar to UW141 (originally designated as 007A), which we found to exhibit active twitching motility, because both were isolated by Hayward from ginger plants in Australia during April, 1965. Henrichsen \& Blom (1975) observed polar pili on what appears to be the same biovar 2 strain as used by Fuerst \& Hayward (1969). More recently, a pilin protein was purified two separate times from K60 (Stemmer \& Sequeira, 1987; Young et al., 1985), and neither the molecular mass $(9 \cdot 5 \mathrm{kDa})$ nor the amino acid compositions matched either $R$. solanacearum HrpY pilin or typical Tfp. Because these authors used very different culture conditions and methods to observe or isolate pili, the discrepancies in their results do not necessarily indicate production of different pili.

In contrast to the results with other $\mathrm{Tfp}^{-}$phytopathogenic bacteria, eliminating the PilQ secretin in $R$. solanacearum (and presumably Tfp, since the mutants were nonmotile), markedly reduced virulence on tomato plants, indicating that motility and/or $\mathrm{Tfp}$ play a significant role during pathogenesis. Although there was no change in type II or type III protein secretion or in EPS1 production when pilQ was inactivated, we cannot exclude the possibility that loss of this outer-membrane protein has unknown secondary effects. Addressing this concern will require additional work to make a mutant that is defective only in synthesis of the pilin subunit. Nevertheless, that twitching motility appears to be negatively regulated by PhcA, the global virulence regulator, supports the likelihood that motility and/or Tfp are important factors in pathogenesis. Regulation of twitching appears to be on a separate circuit from most other known virulence and pathogenicity factors, since none of the other 12 regulatory genes or two-component systems tested seemed to have any effect. However, we did not test the $R$. solanacearum pehSR two-component system, which positively regulates both transcription of peh $A$, the endo-polygalacturonase structural gene, and flagellar motility (Allen et al., 1997; Tans-Kersten et al., 2001). Based on the similarity of PehS and PehR to the two-component regulatory system that regulates pilin synthesis in $P$. aeruginosa, Allen et al. (1997) speculated that this system might also positively regulate $\mathrm{Tfp}$ production in $R$. solanacearum. Because expression of pehSR is negatively controlled by PhcA (Allen et al., 1997), our observation of prolonged twitching motility by $p h c A$ mutants supports this proposed regulatory pathway.

It is interesting to consider why type IV piliation is more important for virulence of $R$. solanacearum than it appears to be for $X$. campestris or $P$. syringae. One explanation might be that, because $R$. solanacearum must systemically colonize tomato plants to cause disease symptoms (Saile et al., 1997; T. P. Denny, unpublished observations), it has different requirements for Tfp in planta than do the other pathogens tested, which cause only localized lesions. It would be premature to suggest what these requirements might be, because the process of systemic colonization of a host by $R$. solanacearum is not well understood. Another possibility is that contact with and invasion of unwounded tomato roots by $R$. solanacearum when poured into the soil is a more demanding process than that when the foliar pathogens are sprayed directly onto leaf surfaces. It also is fair to wonder what role twitching motility might have for $R$. solanacearum in natural settings. Here, the best possibility is that, as proposed for M. xanthus and P. aeruginosa (Wall \& Kaiser, 1999), which are common soil microbes, Tfp-mediated migration over surfaces could promote acquisition of nutrients. Regardless of whether these explanations are correct, our results with $R$. solanacearum reinforce the conclusion by Semmler et al. (1999) that twitching motility is a highly organized process requiring cell-cell interactions similar to the social gliding motility in $M$. xanthus, rather than the slow, disorganized mode of movement by individual cells originally proposed by 
Henrichsen (1972). Consequently, the role of twitching motility for pathogenesis and survival of $R$. solanacearum will be all the more interesting and important to understand.

\section{ACKNOWLEDGEMENTS}

This work was supported by US Department of Agriculture NRICGP grant 97-35303-4870, and by State and Hatch funds awarded by the University of Georgia Agriculture Experiment Station.

\section{REFERENCES}

Allen, C., Gay, J. \& Simon-Buela, L. (1997). A regulatory locus, pehSR, controls polygalacturonase production and other virulence functions in Ralstonia solanacearum. Mol Plant-Microbe Interact 9, 1054-1064.

Alm, R. A. \& Mattick, J. S. (1997). Genes involved in the biogenesis and function of type-4 fimbriae in Pseudomonas aeruginosa. Gene 192, 89-98.

Altschul, S. F., Madden, T. L., Schaffer, A. A., Zhang, J., Zhang, Z., Webb, M. \& Lipman, D. J. (1997). Gapped BLAST and PSI-BLAST : a new generation of protein database search programs. Nucleic Acids Res 25, 3389-3402.

Araud-Razou, I., Vasse, J., Montrozier, H., Etchebar, C. \& Trigalet, A. (1998). Detection and visualization of the major acidic exopolysaccharide of Ralstonia solanacearum and its role in tomato root infection and vascular colonization. Eur J Plant Pathol 104, 795-809.

Ausubel, F. M., Brent, R., Kingston, R. E., Moore, D. D., Seidman, J. G., Smith, J. A. \& Struhl, K. (1989). Short Protocols in Molecular Biology. New York: Green Publishing Associates and WileyInterscience.

Bertolla, F., van Gijsegem, F., Nesme, X. \& Simonet, P. (1997). Conditions for natural transformation of Ralstonia solanacearum. Appl Environ Microbiol 63, 4965-4968.

Bradley, D. E. (1980). A function of Pseudomonas aeruginosa PAO polar pili: twitching motility. Can J Microbiol 26, 146-154.

Brito, B., Marenda, M., Barberis, P., Boucher, C. \& Genin, S. (1999). prhJ and $h r p G$, two new components of the plant signaldependent regulatory cascade controlled by PrhA in Ralstonia solanacearum. Mol Microbiol 31, 237-251.

Brumbley, S. M. \& Denny, T. P. (1990). Cloning of $p h c A$ from wild-type Pseudomonas solanacearum, a gene that when mutated alters expression of multiple traits that contribute to virulence. $J$ Bacteriol 172, 5677-5685.

Carney, B. F. \& Denny, T. P. (1990). A cloned avirulence gene from Pseudomonas solanacearum determines incompatibility on Nicotiana tabacum at the host species level. J Bacteriol 172, 4836-4843.

Chen, W. P. \& Kuo, T. T. (1993). A simple and rapid method for the preparation of gram-negative bacterial genomic DNA. Nucleic Acids Res 21, 2260.

Clough, S. J., Schell, M. A. \& Denny, T. P. (1994). Evidence for involvement of a volatile extracellular factor in Pseudomonas solanacearum virulence gene expression. Mol Plant-Microbe Interact 7, 621-630.

Clough, S. J., Flavier, A. B., Schell, M. A. \& Denny, T. P. (1997a). Differential expression of virulence genes and motility in Ralstonia (Pseudomonas) solanacearum during exponential growth. Appl Environ Microbiol 63, 844-850.
Clough, S. J., Lee, K.-E., Schell, M. A. \& Denny, T. P. (1997b). A two-component system in Ralstonia (Pseudomonas) solanacearum modulates production of PhcA-regulated virulence factors in response to 3-hydroxypalmitic acid methyl ester. J Bacteriol 179, 3639-3648.

Cook, D. \& Sequeira, L. (1991). Genetic and biochemical characterization of a Pseudomonas solanacearum gene cluster required for extracellular polysaccharide production and for virulence. J Bacteriol 173, 1654-1662.

Cook, D., Barlow, E. \& Sequeira, L. (1989). Genetic diversity of Pseudomonas solanacearum: detection of restriction fragment length polymorphisms with DNA probes that specify virulence and the hypersensitive response. Mol Plant-Microbe Interact 2 , 113-121.

Cornelis, G. R. \& van Gijsegem, F. (2000). Assembly and function of type III secretory systems. Annu Rev Microbiol 54, 735-774.

Darzins, A. (1993). The pilG gene product, required for Pseudomonas aeruginosa pilus production and twitching motility, is homologous to the enteric, single-domain response regulator CheY. J Bacteriol 175, 5934-5944.

Denny, T. P., Makini, F. W. \& Brumbley, S. M. (1988). Characterization of Pseudomonas solanacearum Tn5 mutants deficient in extracellular polysaccharide. Mol Plant-Microbe Interact 1, 215-223.

Denny, T. P., Carney, B. F. \& Schell, M. A. (1990). Inactivation of multiple virulence genes reduces the ability of Pseudomonas solanacearum to cause wilt symptoms. Mol Plant-Microbe Interact 3, 293-300.

van Doorn, J., Boonekamp, P. M. \& Oudega, B. (1994). Partial characterization of fimbriae of Xanthomonas campestris pv. byacinthi. Mol Plant-Microbe Interact 7, 334-344.

Fernandez, L. A. \& Berenguer, J. (2000). Secretion and assembly of regular surface structures in Gram-negative bacteria. FEMS Microbiol Rev 24, 21-44.

Flavier, A. B., Ganova-Raeva, L. M., Schell, M. A. \& Denny, T. P. (1997). Hierarchical autoinduction in Ralstonia solanacearum: control of acyl-homoserine lactone production by a novel autoregulatory system responsive to 3-hydroxypalmitic acid methyl ester. J Bacteriol 179, 7089-7097.

Flavier, A. B., Schell, M. A. \& Denny, T. P. (1998). An RpoS $\left(\sigma^{\mathrm{S}}\right)$ homologue regulates acylhomoserine lactone-dependent autoinduction in Ralstonia solanacearum. Mol Microbiol 28, 475-486.

Fuerst, J. A. \& Hayward, A. C. (1969). Surface appendages similar to fimbriae (pili) on Pseudomonas species. J Gen Microbiol 58, 227-237.

Fussenegger, M., Rudel, T., Barten, R., Ryll, R. \& Meyer, T. F. (1997). Transformation competence and type-4 pilus biogenesis in Neisseria gonorrhoeae - a review. Gene 192, 125-134.

Galan, J. E., Ginocchio, C. \& Costeas, P. (1992). Molecular and functional characterization of the Salmonella invasion gene invA: homology of InvA to members of a new protein family. $J$ Bacteriol 174, 4338-4349.

Genin, S. \& Boucher, C. A. (1994). A superfamily of proteins involved in different secretion pathways in Gram-negative bacteria : modular structure and specificity of the $\mathrm{N}$-terminal domain. Mol Gen Genet 243, 112-118.

van Gijsegem, F., Gough, C., Zischek, C. \& 7 other authors (1995). The hrp gene locus of Pseudomonas solanacearum, which controls the production of a type III secretion system, encodes eight proteins related to components of the bacterial flagellar biogenesis complex. Mol Microbiol 15, 1095-1114.

van Gijsegem, F., Vasse, J., Camus, J. C., Marenda, M. \& Boucher, 
C. (2000). Ralstonia solanacearum produces Hrp-dependent pili that are required for PopA secretion but not for attachment of bacteria to plant cells. Mol Microbiol 36, 249-260.

Hayward, A. C. (2000). Ralstonia solanacearum. In Encyclopedia of Microbiology, vol. 4, pp. 32-42. Edited by J. Lederberg. San Diego, CA : Academic Press.

Henrichsen, J. (1972). Bacterial surface translocation: a survey and a classification. Bacteriol Rev 36, 478-503.

Henrichsen, J. (1975a). The occurence of twitching motility among gram-negative bacteria. Acta Pathol Microbiol Scand Sect B 83, 171-178.

Henrichsen, J. (1975b). The influence of changes in the environment on twitching motility. Acta Pathol Microbiol Scand Sect B 83, 179-186.

Henrichsen, J. (1983). Twitching motility. Annu Rev Microbiol 37, 81-93.

Henrichsen, J. \& Blom, J. (1975). Examination of fimbriation of some Gram-negative rods with and without twitching and gliding motility. Acta Pathol Microbiol Scand Sect B 83, 161-170.

Huang, Q. \& Allen, C. (1997). An exo-poly- $\alpha$-D-galacturonosidase, $\mathrm{PehB}$, is required for wild-type virulence of Ralstonia solanacearum . J Bacteriol 179, 7369-7378.

Huang, J., Carney, B. F., Denny, T. P., Weissinger, A. K. \& Schell, M. A. (1995). A complex network regulates expression of $e p s$ and other virulence genes of Pseudomonas solanacearum. J Bacteriol $177,1259-1267$.

Hueck, C. J. (1998). Type III protein secretion systems in bacterial pathogens of animals and plants. Microbiol Mol Biol Rev 62, 379-433.

Kagami, Y., Ratliff, M., Surber, M., Martinez, A. \& Nunn, D. N. (1998). Type II protein secretion by Pseudomonas aeruginosa: genetic suppression of a conditional mutation in the pilin-like component XcpT by the cytoplasmic component XcpR. Mol Microbiol 27, 221-233.

Kang, Y., Huang, J. Z., Mao, G. Z., He, L. Y. \& Schell, M. A. (1994). Dramatically reduced virulence of mutants of Pseudomonas solanacearum defective in export of extracellular proteins across the outer membrane. Mol Plant-Microbe Interact 7, 370-377.

Kang, Y., Saile, E., Schell, M. A. \& Denny, T. P. (1999). Quantitative immunofluorescence of regulated eps gene expression in single cells of Ralstonia solanacearum. Appl Environ Microbiol 65 , 2356-2362.

Keen, N. T., Tamaki, S., Kobayashi, D. \& Trollinger, D. (1988). Improved broad-host-range plasmids for DNA cloning in gramnegative bacteria. Gene 70, 191-197.

Kitten, T. \& Willis, D. K. (1996). Suppression of a sensor kinasedependent phenotype in Pseudomonas syringae by ribosomal proteins L35 and L20. J Bacteriol 178, 1548-1555.

Lory, S. \& Strom, M. S. (1997). Structure-function relationship of type-IV prepilin peptidase of Pseudomonas aeruginosa - a review. Gene 192, 117-121.

McGarvey, J. A., Denny, T. P. \& Schell, M. A. (1999). Spatialtemporal and quantitative analysis of growth and EPS I production by Ralstonia solanacearum in resistant and susceptible tomato cultivars. Phytopathology 89, 1233-1239.

Marenda, M., Brito, B., Callard, D., Genin, S., Barberis, P., Boucher C. \& Arlat, M. (1998). PrhA controls a novel regulatory pathway required for the specific induction of Ralstonia solanacearum hrp genes in the presence of plant cells. Mol Microbiol 27, 437-453.

Matthysse, A. G., Stretton, S., Dandie, C., McClure, N. C. \& Goodman, A. E. (1996). Construction of GFP vectors for use in
Gram-negative bacteria other than Escherichia coli. FEMS Microbiol Lett 145, 87-94.

Merz, A. J., So, M. \& Sheetz, M. P. (2000). Pilus retraction powers bacterial twitching motility. Nature 407, 98-102.

Miller, J. H. (1972). Experiments in Molecular Genetics. Cold Spring Harbor, NY : Cold Spring Harbor Laboratory.

Nunn, D. (1999). Bacterial type II protein export and pilus biogenesis: more than just homologies? Trends Cell Biol 9, 402-408.

O'Toole, G. A. \& Kolter, R. (1998). Flagellar and twitching motility are necessary for Pseudomonas aeruginosa biofilm development. Mol Microbiol 30, 295-304.

Ojanen-Reuhs, T., Kalkkinen, N., Westerlund-Wikstrom, B., van Doorn, J., Haahtela, K., Nurmiaholassila, E. L., Wengelnik, K., Bonas, U. \& Korhonen, T. K. (1997). Characterization of the fimA gene encoding bundle-forming fimbriae of the plant pathogen Xanthomonas campestris pv. vesicatoria. J Bacteriol 179, 1280-1290.

Pugsley, A. P. (1993). The complete general secretory pathway in Gram-negative bacteria. Microbiol Rev 57, 50-108.

Roine, E., Raineri, D. M., Romantschuk, M., Wilson, M. \& Nunn, D. N. (1998). Characterization of type IV pilus genes in Pseudomonas syringae pv. tomato DC3000. Mol Plant-Microbe Interact 11, 1048-1056.

Saile, E., Schell, M. A. \& Denny, T. P. (1997). Role of extracellular polysaccharide and endoglucanase in root invasion and colonization of tomato plants by Ralstonia solanacearum. Phytopathology 87, 1264-1271.

Schell, M. A. (2000). Control of virulence and pathogenicity genes of Ralstonia solanacearum by an elaborate sensory array. Annu Rev Phytopathol 38, 263-292.

Schweizer, H. P. (1993). Small broad-host-range gentamycin resistance gene cassettes for site-specific insertion and deletion mutagenesis. BioTechniques 15, 831-833.

Semmler, A. B. T., Whitchurch, C. B. \& Mattick, J. S. (1999). A reexamination of twitching motility in Pseudomonas aeruginosa. Microbiology 145, 2863-2873.

Simpson, A. J. G., Reinach, F. C., Arruda, P. \& 112 other authors (2000). The genome sequence of the plant pathogen Xylella fastidiosa. Nature 406, 151-159.

Skerker, J. M. \& Berg, H. C. (2001). Direct observation of extension and retraction of type IV pili. Proc Natl Acad Sci USA 98, 6901-6904.

Staskawicz, B., Dahlbeck, D., Keen, N. \& Napoli, C. (1987). Molecular characterization of cloned avirulence genes from race 0 and race 1 of Pseudomonas syringae pv. glycinea. J Bacteriol 169, 5789-5794.

Stemmer, W. P. C. \& Sequeira, L. (1987). Fimbriae of phytopathogenic and symbiotic bacteria. Phytopathology 77, 1633-1639.

Strom, M. S. \& Lory, S. (1993). Structure-function and biogenesis of the type IV pili. Annu Rev Microbiol 47, 565-596.

Su, W. C., Tung, S. Y., Yang, M. K. \& Kuo, T. T. (1999). The pilA gene of Xanthomonas campestris pv. citri is required for infection by the filamentous phage cf. Mol Gen Genet 262, 22-26.

Sun, H., Zusman, D. R. \& Shi, W. Y. (2000). Type IV pilus of Myxococcus xanthus is a motility apparatus controlled by the $f r z$ chemosensory system. Curr Biol 10, 1143-1146.

Tans-Kersten, J., Guan, Y. F. \& Allen, C. (1998). Ralstonia solanacearum pectin methylesterase is required for growth on methylated pectin but not for bacterial wilt virulence. Appl Environ Microbiol 64, 4918-4923. 
Tans-Kersten, J., Huang, H. Y. \& Allen, C. (2001). Ralstonia solanacearum needs motility for invasive virulence on tomato. $J$ Bacteriol 183, 3597-3605.

Titarenko, E., Lopez-Solanilla, E., Garcia-Olmedo, F. \& RodriguezPalenzuela, P. (1997). Mutants of Ralstonia (Pseudomonas) solanacearum sensitive to antimicrobial peptides are altered in their lipopolysaccharide structure and are avirulent in tobacco. $J$ Bacteriol 179, 6699-6704.

Wall, D. \& Kaiser, D. (1999). Type IV pili and cell motility. Mol Microbiol 32, 1-10.

Wall, D., Kolenbrander, P. E. \& Kaiser, D. (1999). The Myxococcus xanthus pilQ ( $\mathrm{sgl}$ lA) gene encodes a secretin homolog required for type IV pilus biogenesis, social motility, and development. $J$ Bacteriol 181, 24-33.

Wolfgang, M., Park, H. S., Hayes, S. F., van Putten, J. P. M. \& Koomey, M. (1998). Suppression of an absolute defect in Type IV pilus biogenesis by loss-of-function mutations in pilT, a twitching motility gene in Neisseria gonorrboeae. Proc Natl Acad Sci US A 95, 14973-14978.

Wolfgang, M., van Putten, J. P., Hayes, S. F., Dorward, D. \& Koomey, M. (2000). Components and dynamics of fiber formation define a ubiquitous biogenesis pathway for bacterial pili. EMBO J 19, 6408-6418.

Young, D. H., Stemmer, W. P. C. \& Sequeira, L. (1985). Reassembly of a fimbrial hemagglutinin from Pseudomonas solanacearum after purification of the subunit by preparative sodium dodecyl sulfate-polyacrylamide gel electrophoresis. Appl Environ Microbiol 50, 605-610.

Received 10 July 2001; revised 27 September 2001; accepted 3 October 2001. 